\title{
Hydrothermal Cu-Co-Au ore formation during the Mesoarchean: Implications for Archean $\mathrm{Cu}-\mathrm{Co}$ metallogenesis
}

DAVID FoX ${ }^{1,2 *}$, SAMUEL SPINKS ${ }^{1}$, MARK PEARCE ${ }^{1}$, MiLO BARHAM $^{2}$, CHRIS KIRKLAND ${ }^{2}$, LAURE MARTIN ${ }^{3}$, MEHROOZ ASPANDIAR ${ }^{2}$

${ }^{1}$ CSIRO Mineral Resources, Australia

(*David.fox1@csiro.au)

${ }^{2}$ The Institute for Geoscience Research (TIGeR), School of

Earth and Planetary Sciences, Curtin University

${ }^{3}$ Centre for Microscopy, Characterisation and Analysis,

University of Western Australia

Through geological time, hydrothermal $\mathrm{Cu}-\mathrm{Co}-\mathrm{Au}$ mineralisation is generally limited to terranes of Proterozoic age or younger; occurring overwhelmingly in stratiform sediment-hosted $\mathrm{Cu}$ (SSC) deposits [1]. As $\mathrm{Cu}$ and $\mathrm{Co}$ are redox-sensitive metals, their mobility is strongly controlled by the availability of oxygen. Reflecting this, the rarity of significant Archean hydrothermal $\mathrm{Cu}-\mathrm{Co}$ mineralisation is generally believed to reflect the absence of globally widespread oxygenated conditions prior to the Great Oxygenation Event (GOE) around 2.4 Ga [2,3]. Here we present isotopic, geochronological, and mineralogical evidence of the genesis of Carlow Castle $\mathrm{Cu}-\mathrm{Co}-\mathrm{Au}$ deposit (8 Mt @ 0.51\% Cu, 0.08\% Co, 1.6g/t Au) [4]. Carlow Castle is a recently discovered structurally-hosted $\mathrm{Cu}-\mathrm{Co}-\mathrm{Au}$ deposit within a sheared Paleoarchean volcano-sedimentary greenstone sequence in the Pilbara Craton of northwest Western Australia [5]. Our research indicates that Carlow Castle formed during a period of rifting in the northwest Pilbara Craton during the Mesoarchean. This suggests that the processes necessary to form significant $\mathrm{Cu}-\mathrm{Co}-\mathrm{Au}$ mineralisation did operate during the Archean, contrary to conventionally accepted models of $\mathrm{Cu}-\mathrm{Co}-\mathrm{Au}$ metallogenesis through geological time. This has important implications for our understanding of $\mathrm{Cu}-\mathrm{Co}-\mathrm{Au}$ metallogenesis through Earth history; suggesting that there is potential for the existence of other hitherto undiscovered hydrothermal $\mathrm{Cu}-\mathrm{Co}-\mathrm{Au}$ mineralisation in Archean greenstone terranes.

[1] Hitzman, et al. (2017), Cobalt-Styles of Deposits and the Search for Primary Deposits. U.S. Geological Survey. [2] Brown AC (2014). Treatise on Geochemistry, 13. [3] Lyons, Reinhard, Planavsky (2014). Nature 506, 307-315. [4] Artemis Resources Ltd. (2019), ASX: www.asx.com.au/asxpdf/20191120/pdf/44brd03vh31ncw.pdf [5] Fox, et al. (2019), Economic Geology 114(6), 1021-1031. 